\title{
Leydig cell tumor of the testis presenting with gynaecomastia due to hyperprolactinemia after orchiectomy
}

Yordanka Pina Rivera ${ }^{1,2}$, Godfrey Mutashambara Rwegerera*1,2, Wahhab Chowdhury ${ }^{3}$, Kudra Jumanne Chobanga ${ }^{4,5}$, Alexei Ortiz Milan ${ }^{6}$

${ }^{1}$ Faculty of Medicine, Department of Internal Medicine, University of Botswana, Gaborone, Botswana

${ }^{2}$ Department of Medicine, Princess Marina Hospital, Gaborone, Botswana

${ }^{3}$ Department of Histopathology, National Health Laboratory, Gaborone, Botswana

${ }^{4}$ Department of Gynaecology and Obstetrics, University of Botswana, Gaborone, Botswana

${ }^{5}$ Department of Gynaecology, Princess Marina Hospital, Gaborone, Botswana

${ }^{6}$ Department of Emergency Medicine, University of Botswana, Gaborone, Botswana

Received: July 2, 2017

DOI: $10.5430 /$ crim.v4n $4 \mathrm{p} 28$
Accepted: September 27, $2017 \quad$ Online Published: October 10, 2017

URL: https://doi.org/10.5430/crim.v4n4p28

\begin{abstract}
Leydig cell tumors (LCT) are rare and represent $1 \%$ to $3 \%$ of all tumors of the testis. LCTs can either be benign or malignant with clinical presentation varying from testicular mass associated with endocrinal manifestations to metastatic lesions in case of malignant tumors. We describe a 25-year-old man who presented with an isolated painless mass of the left testes which was confirmed by ultrasonography. An orchiectomy was subsequently performed and the histopathological analysis revealed a leydig cell tumor. Three months after surgery, the patient presented with bilateral gynaecomastia; estradiol, testosterone and gonadotropin levels as well as tumor markers (carcinoembryonic antigen (CEA), alpha-fetoprotein (AFP) and human chorionic gonadotropin $(\beta$-HCG) were within normal ranges but prolactin was high in two different measurements. No evidence of tumor recurrence or metastases was found and different underlying causes of hyperprolactinemia including use of drugs, pituitary adenoma, hypothyroidism and renal failure were ruled out. After 6 month of treatment with Cabergoline the prolactin level and breast size were remarkably reduced. Patients with benign LCT have a favourable prognosis but in order to rule out tumor recurrence or a persistent effect of their hormonal disorder, follow-up should include regular hormonal and imaging studies.
\end{abstract}

Key Words: Testicular neoplasm, Orchiectomy, Male breast enlargement, Hyperprolactinemia

\section{INTRODUCTION}

Leydig cell tumors (LCT) are the most common non-germ cell tumors of the testis accounting for $1 \%-3 \%$ of all testicular tumors. ${ }^{[1]}$ They are composed predominantly of focal or diffuse hyperplasia of interstitial cells with atrophy of seminiferous tubules whenever the tumor is large..$^{[2,3]}$

LCT can occur at any age, although two peaks of maximum incidence are reported at ages between 5 and 10 years and between 25 and 35 years of age. ${ }^{[4,5]}$ LCT are predominantly benign, although $10 \%$ of cases are malignant. ${ }^{[6]}$ The tumors

\footnotetext{
*Correspondence: Godfrey Mutashambara Rwegerera; Email: grwege @yahoo.com; Address: Department of Internal Medicine, Faculty of Medicine, University of Botswana, Private Bag 00713, Gaborone, Botswana.
} 
present with a palpable testicular mass in about $80 \%$ to $90 \%$ of cases ${ }^{[7]}$ and are associated with endocrinal manifestations that are variable according to the age at appearance of the tumor. About $20 \%$ to $40 \%$ of adults present with gynecomastia with or without decreased libido, impotence, contralateral testicular atrophy and infertility secondary to azoospermia. ${ }^{[8,9]}$ In contrast, children present with masculinization manifestations. ${ }^{[10]}$

Gynecomastia in LCTs may occur as a result of several endocrine dysfunctions. It can be due to increase of estrogens produced directly by the tumor as a result of stimulation by human chorionic gonadotrophin $(\mathrm{hcG})^{[11]}$ or the consequence of the aromatization of other sexual steroids ${ }^{[8]}$ or due to hyperoestrogenaemia. ${ }^{[12]}$ Gynecomastia can occur preceding detection of a tumor by several months to years and its presence is a good prognostic sign. ${ }^{[7]}$ Majority of cases of gynecomastia regress spontaneously after orchiectomy; likewise testosterone and oestrogen tend to normalize after surgery; about $20 \%$ of cases of gynaecomastia persist after orchiectomy, hence requiring surgical intervention. ${ }^{[7,13]}$

We present a 25-year-old man who presented with a rare case of LCT and developed gynaecomastia after orchiectomy. The diagnostic and therapeutic management is also discussed.

\section{CASE PRESentation}

A 25-year-old male presented to urology clinic with history of progressive growing painless mass on his left testis. He reported that the mass was observed at the age of 11 years. Other symptoms were thick yellowish semen which was smelly, decreased libido and impotence. He also noted progressive hair loss (alopecia). There was not history of cryptorchidism or family history of malignancy. Physical examination at the time of presentation was consistent with a firm 2-4 cm, non-tender well circumscribed mass in the left testis. At this point, there was neither gynaecomastia nor palpable lymph nodes.

Scrotal and abdomen ultrasound revealed normal right testis and left testicular enlargement with multinodular appearance. The size of the mass ranged between $0.5 \mathrm{~cm}$ and $1.5 \mathrm{~cm}$ in diameter; with no evidence of hydrocele. There was no evidence of retroperitoneal lymphadenopathy or hepatic metastasis. Tumor markers including carcinoembryonic antigen (CEA), alpha-fetoprotein (AFP) and human chorionic gonadotropin $(\beta$-HCG) were within normal range. Testosterone was normal but estradiol, prolactin and gonadotrophins levels were not measured at that moment. Pelvic, abdomen and chest Computerized Tomography scans were done and metastatic lesions were not observed.

Published by Sciedu Press

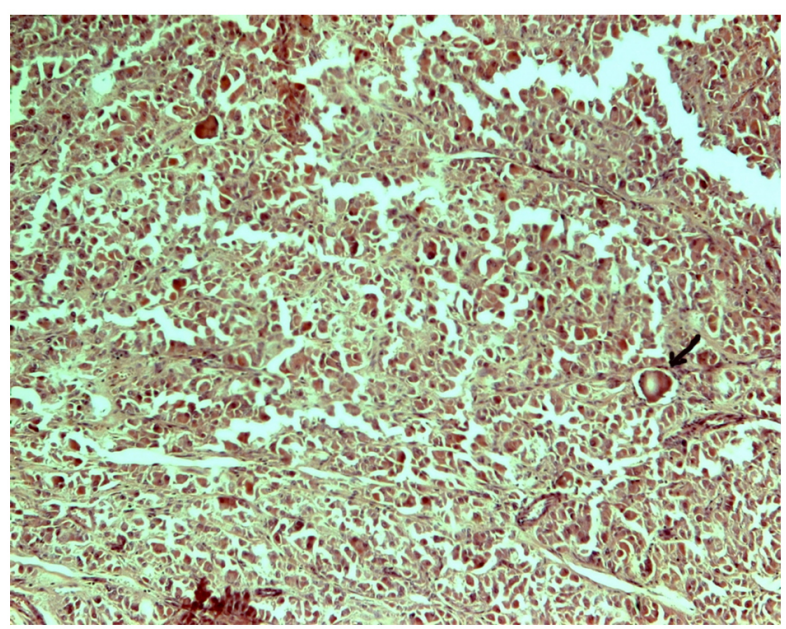

Figure 1. Globular inclusion of eosinophilic materials (Precursor of Reinke crystals)

Patient underwent left orchiectomy. Grossly, resected specimen showed a well circumscribed yellow-tan multilobulated mass $(6 \mathrm{~cm} \times 6 \mathrm{~cm} \times 6 \mathrm{~cm})$ confined to the testis with invasion into peritumor tissue but sparing the epididymis. The tumour was $5 \mathrm{~cm}$ away from the nearest spermatic cord resection margin. There was an area of haemorrhage and necrosis which measured $2 \mathrm{~cm} \times 0.5 \mathrm{~cm} \times 0.5 \mathrm{~cm}$; as well a small ring of testicular parenchyma was noted. Microscopy revealed large cells with abundant acidophilic cytoplasm, some looked rhabdomatoid and others were plasmacytoid (Reinke crystals) (see Figure 1). There were sheets of polygonal cells, large nuclei and moderate size central nucleolus with moderate variation in size (see Figure 2). The nucleus showed mild atypia with scanty mitoses.

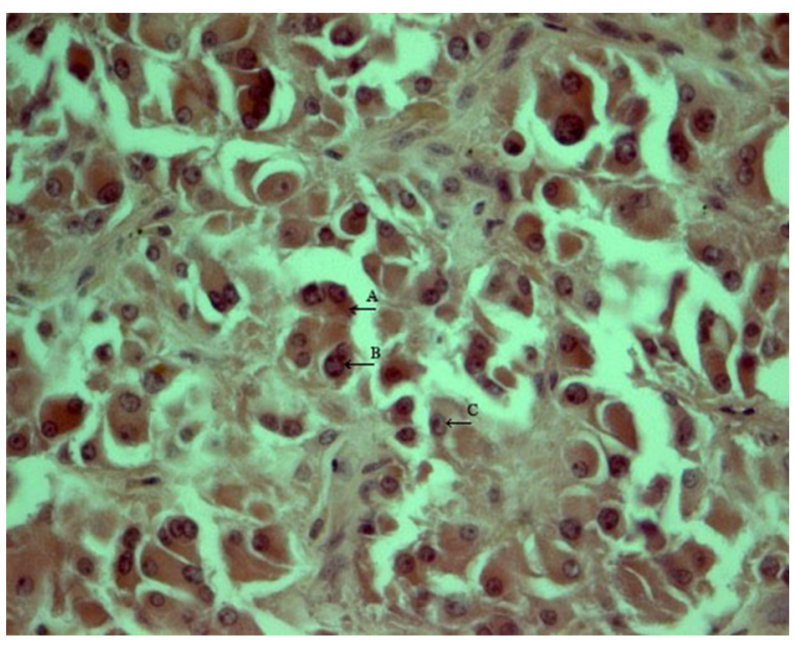

Figure 2. Sheets of polygonal cells, large amount of eosinophilic cytoplasm (A), large nuclei (B) and moderate size central nucleolus (C) with moderate variation in size

Tumor markers (CEA, AFP and $\beta$-HCG) done three months 
postoperatively were within normal ranges. Three month postoperatively, patient was seen at urology clinic and referred to Endocrinology clinic as at the time he was complaining of bilateral breast enlargement and complete loss of libido. He denied dieting, drug ingestion or excessive use of alcohol. On physical examination he appeared well nourished and breast enlargement was moderate, bilateral and symmetrical (see Figure 3). Right testicule was normal in size and consistence and no mass was noted, no inguinal lymph node was palpated. Breast ultrasonography showed increased bilateral mammary glands, compatible with gynaecomastia. Testicular, pelvic and abdominal ultrasound was done and no evidence of tumor recurrence or metastasis was seen.

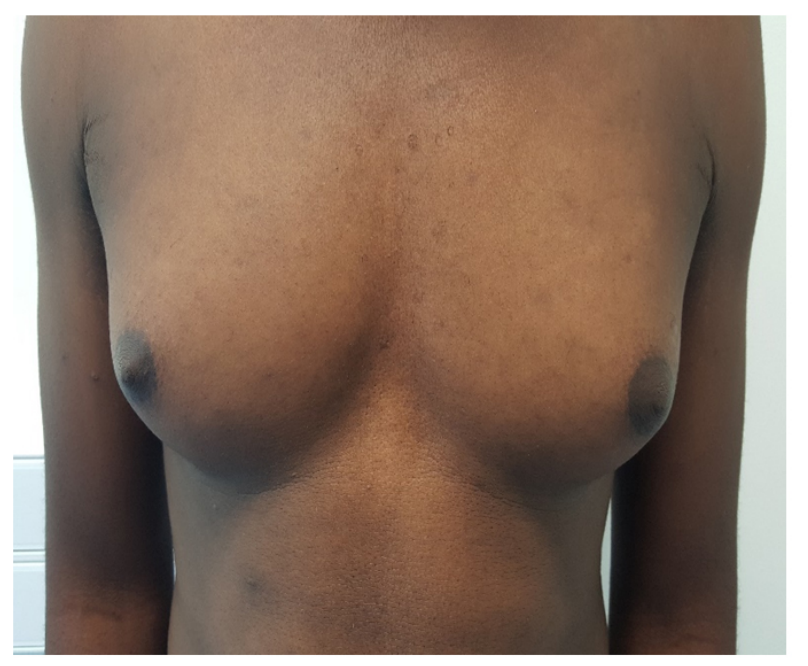

Figure 3. Bilateral and symmetrical gynecomastia

Hormonal profile showed gonadotropins (FSH and LH), testosterone, free testosterone index and estradiol within the normal range. Tumor markers including alpha-feto protein, beta-hcG and carcinoembryonic antigen were within normal range. Thyroid function tests were also within normal range. Surprisingly; serum Prolactin was markedly elevated in two (2) different measurements, the results were $42.13 \mathrm{ng} / \mathrm{ml}$ and $41.49 \mathrm{ng} / \mathrm{ml}(4.46-19.40 \mathrm{ng} / \mathrm{ml})$ respectively. Magnetic Resonant Imaging (MRI) of the pituitary gland ruled out a possibility of a prolactin producing tumor. Findings of hormone profile and imaging led to the definitive diagnosis of gynaecomastia secondary to hyperprolactinemia on the background of resected leydig cell tumor. Patient was treated with Cabergoline $0.5 \mathrm{mg}$ per os twice a week with resulting clinical improvement of breast size to almost baseline after six months of treatment; likewise serum prolactin level markedly decreased to within normal range within six months.

\section{Discussion}

LCTs tend to have endocrine activities producing a range of hormones such as oestrogen, testosterone, follicular stimulating hormone and luteinizing hormone. ${ }^{[8,14]}$

LCT present with variable clinical manifestations; majority of patients $(80 \%-90 \%)$ present in adult hood like it was for the case of our patient, at presentation usually a painless testicular mass felt by the patient is the reason for seeking medical attention. About $30 \%$ of patients present with endocrine manifestations. ${ }^{[3]}$ Our index patient presented with both a painless mass and endocrine features. Most of the time, LCTs are unilateral, though it is important to remember that about $3 \%-10 \%$ are bilateral either at presentation or latter during the course of follow up, ${ }^{[15,16]}$ hence highlighting the importance of close follow up and monitoring even after orchiectomy.

Scrotal ultrasound is very useful to confirm presence of testicular tumor, however it cannot differentiate whether the tumor is benign or malignant. ${ }^{[17]}$ Likewise in our patient, ultrasound confirmed presence of tumor; histology was necessary to arrive at definitive diagnosis of leydig cell tumor.

Histology is important in differentiating benign from malignant tumor as presence of three or more out of seven histology features makes malignancy more likely; however as documented previously presence of metastasis is best indicator of malignancy due to the fact that for LCTs histology is always inconclusive. ${ }^{[18,19]}$ In the presented patient; the anatomical-pathological study confirmed the diagnosis of leydig cell tumor and among seven criteria to suggest malignant behavior, three were present: Tumor size more than $5 \mathrm{~cm}(6$ $\mathrm{cm}$ ), presence of massive coagulation necrosis and presence of early invasion into peritumor tissue. The negative criteria were: no vascular invasion, nuclear atypia not marked, no frequent mitoses and absence of lipofuscin pigments. Our patient was categorized as having benign LCT despite having three histological features because there was no evidence of metastasis either at presentation or during follow up.

Age at presentation has also been described to be a predictor of malignancy. Malignant LCT have not been described in children ${ }^{[8,20]}$ with malignant behavior occurring mostly in older patients at 5 th to 6 th decade of life..$^{[2,3,21,22]}$ Our patient symptoms started in childhood and continued to adulthood making malignancy highly unlikely.

Tumor markers assessment is an important aspect of work up in patients with testicular tumors; this arise from the fact that some germ cell tumors which are potentially malignant tend to produce tumor markers like human chorionic gonadotropin (hCG). ${ }^{[23,24]}$ Tumor markers differentiate testicular malig- 
nancy before one can stick to endocrinal syndrome. Pure LCT do not produce any tumor markers ${ }^{[23,24]}$ as it occurred in our patient.

Gynaecomastia sometimes precedes detection of LCTs and is a common clinical presentation in LCT, it can be explained by high levels of estrogen which is either from the peripheral conversion of androstenedione and testosterone on estrone and estradiol $(75 \%-90 \%)$ or secreted by the tumor $(10 \%$ $25 \%)$ of cases. ${ }^{[9]}$

Our presented case is peculiar because gynaecomastia appeared after orchiectomy. Despite the fact that oestrogen levels were not performed before surgery we do believe that our patient had higher levels of oestrogen because of clinical manifestations suggesting the former and hypogonadism preoperatively which included reduced libido and alopecia. Work up to determine the cause of gynaecomastia revealed normal hormonal profile except for hyperprolactinemia.

The link between hyperprolactinemia and leydig cell tumor is related to the high level of estrogens. There are several mechanisms postulated to explain how oestrogen leads to hyperprolactinemia by increasing secretion by adenohypophysis. These include: firstly, oestrogen binds to nuclear receptor in lactophilic cells resulting to gene activation and transcription ultimately increasing mRNA; secondly, oestrogen has antidopaminergic effect hence counteracting ability of dopamine to inhibit prolactin synthesis and secretion; thirdly, oestrogen has an effect of increasing sensitivity of lactating cells to thyrotrophic releasing hormone. ${ }^{[12]}$

On the other hand, hyperprolactinemia induces gynaecomastia by inhibiting endogenous gonadotrophins and testosterone production resulting to stimulation of breast development. ${ }^{[25]}$
Our patient presented with clinical features of hypogonadism and hyperoestrogemia postoperatively suggesting high oestrogen levels, however serum oestrogen levels was persistently within normal range. This finding is not surprising as previous studies have shown discrepancies of oestrogen levels at different locations with levels at spermatic veins being about 6,000 times superior compared to serum levels. ${ }^{[26-28]}$ The higher values at testis level indicate that even the remaining leydig cells in the remaining testis are dysfunctional resulting to endocrine manifestations as seen in our patient. We don't have the capacity to measure oestrogen level at spermatic veins in our facility; hence high oestrogen level though more likely could not be confirmed.

Abnormal hormonal profile after surgery may indicate either tumor recurrence or metastasis. ${ }^{[29,30]}$ We made significant efforts to rule out metastasis and other possible causes of hyperprolactinemia. Therefore, in the absence of any identifiable factors that could explain the maintenance of high levels of Prolactin we suspected it was secondary to the persistent effect of hyperoestrogenaemia and hypogonadism coexisting in patients with LCT postoperatively.

In conclusion, leydig cell tumors are rare and frequently hormonally active with variable clinical manifestations that may appear even after tumor resection. Despite favourable prognosis of LCTs after orchiectomy, long-term follow up is necessary to exclude both recurrence and metastasis. The endocrine profile and imaging investigations need to be repeated periodically in order to diagnose and treat timely, associated conditions.

\section{CONFlicts OF INTEREST Disclosure}

The authors have declared no conflicts of interest.

\section{REFERENCES}

[1] Geminiani J, Marshall SD, Ho TS, et al. Testicular Leydig Cell Tumor with Metachronous Lesions: Outcomes after Metastasis Resection and Cryoablation. Case Reports in Urology. 2015; 2015: 748495. PMid:26525589 https : //doi.org/10.1155/2015/748495

[2] Villamil A, Mundo ME, Lema B. Tumor de células intersticiales de testículo. Rev Argentina de Urología. 1992; 57: 135-8.

[3] Tortosa R, Guanter IR, Torrelles VG, et al. Tumor de células de leydig: nuestros casos y revisión de la literatura. Arch Esp Urol. 2006; 59(5): 467-72.

[4] Thomas JC, Ross JH, Kay R. Stromal testis tumors in children: a report from the prepubertal testis tumor registry. J Urol. 2001; 166: 2338-40. https://doi.org/10.1016/S0022-5347(05)6 5583-8

[5] Rich MA, Keating MA. Leydig cell tumors and tumors associated with congenital adrenal hyperplasia. Urol Clin North Am. 2000;
27: 519-28. https://doi.org/10.1016/S0094-0143(05)700 99-9

[6] Roca JPDL, Arrea FA, Arnau LB, et al. Leydig cell tumor of the testis. Arch ESP Urol. 2002; 53: 453-8.

[7] Magalhaes A, Filho CC, Gouveia G, et al. Gynecomastia Secondary of Leydig Cell Tumor: Case Report. Journal of Senologic International society. 2012; 1(3).

[8] Al-Agha OM, Axiotis CA. An in-depth look at Leydig cell tumor of the testis. Arch of Path and Lab Med. 2007; 131 (2): 311-7. PMid:17284120

[9] Roca JPDL, Arrea FA, Arnau LB, et al. Tumor de células de Leydig del testículo. Arch Esp Urol. 2000; 53: 453-8.

[10] Catalá BM, Girbes BJ, Carmenaramón R, et al. Gynecomastia and Leydig cell tumor. An Med Interna. 1997; 14: 131-4.

[11] Duparc C, Boissiere-Veverka G, Lefebvre H, et al. An estrogenproducing seminoma responsible for gynecomastia. Horm Metab 
Res. 2003; 35: 324-9. PMid:12916004 https ://doi .org/10.105 5/s-2003-41310

[12] Melo-Florian A. Hiperprolactinemia: Revision y aspectos relevantes [INTERNET]. VERSIÓN 101. Endocrinologia y nutricion; 2010. Available from: https: //www.scribd.com/document/55448883/Hiperprolactine mia-revision-y-aspectos-relevantes

[13] DMonteiro A, Alves M, Marques O. Hyperprolactinemia and Leydig cell tumor. Endocrine Abstracts. 2015; 37: EP1320.

[14] Carmignani L, Colombo R, Gadda F, et al. Conservative surgical therapy for Leydig cell tumor. J Urol. 2007; 178: 507-11. PMid:17561156 https://doi.org/10.1016/j.juro.2007.03.108

[15] Huang Y, Song J, Xu M, et al. Primary Leydig cell tumor of epididymis: A rare case report with review of literature. Andrology. 2013; 45: 430-3. PMid:23194277 https://doi.org/10.1111/ and. 12049

[16] Betriu GC, Sanchez AT, Ojeda JMD, et al. Tumor de células de Leydig: presentación de ocho casos y revisión de la literatura. Actas Urol. Esp. 2002; 26: 36. https://doi.org/10.1016/S0210-4 806 (02) 72726-5

[17] Kocakoc E, Bhatt SH, Dogra V. Ultrasound evaluation of testicular neoplasm. Ultrasound Clin. 2007; 2: 27-44. https : //doi .org/10 $.1016 /$ j.cult. 2007.01 .006

[18] Agrawal U, Sharma M, Bhatnagar D, et al. Leydig cell tumor: An unusual presentation. Indian J Pathol Microbiol. 2009; 52: 395-6. PMid:19679972 https : //doi .org/10.4103/0377-4929.5500 5

[19] Sengupta S, Chatterjee U, Sarkar K, et al. Leydig cell tumor: A report of two cases with unusual presentation. Indian J Pathol Microbiol. 2010; 53: 796-8. PMid:21045421 https://doi.org/10.4103/ 0377-4929.72096

[20] Piolat C, Dyon JF, Chavanis N, et al. Hyperplasie à cellules de Leydig du testicule chez l'enfant. Prog Urol. 2003; 13: 110-4. PMid:12703364
[21] Young RH, Talerman A. Testicular tumors other than germ cell tumors. Seminars in Diagnostic Pathology. 1987; 4: 342. PMid:2832918

[22] Kim I, Young RH, Scully RE. Leydig cell tumors of the testis: a clinicopathological analysis of 40 cases and review of the literature. Am. J. Surg. Pathol. 1985; 9: 177-92. PMid:3993830 https://doi.org/10.1097/00000478-198503000-00002

[23] Gheorghisan-Galateanu AA. Leydig cell tumors of the testis: A case report. BMC Research Notes. 2014; 7: 656. PMid:25230718 https://doi .org/10.1186/1756-0500-7-656

[24] Tazi MF, Mellas S, El Fassi MJ, et al. Leydig Cell Hyperplasia Revealed by Gynaecomastia. Rev Urol. 2008; 10(2): 164-7. PMid:18660859

[25] Melmed SH, Polonski K, Reed P, et al. Williams textbook of Endocrinology (13th ed). Philadelphia PA. Disorders of the testes and the male reproductive tract; 2016. p. 725.

[26] Abi-Aad AS, Opsomer R, Wese FX, et al. Leydig cell tumor: estradiol level at different locations. J. Urol. 1994; 152: 1009-10. https : //doi .org/10.1016/S0022-5347(17)32644-7

[27] Bercovici JP, Nahoul K, Tater D, et al. Hormonal profile of Leydig cell tumors with gynecomastia. J Clin Endocrinol. Metab. 1984; 59(4): 625-30. PMid:6434575 https ://doi.org/10.1210/jcem $-59-4-625$

[28] Mineur P, Cooman SD, Hustin J, et al. Feminizing testicular Leydig cell tumor: hormonal profile before and after unilateral orchiectomy. J Clin Endocrinol Metab. 1987; 64: 686-91. PMid:3818898 https://doi.org/10.1210/jcem-64-4-686

[29] Mahon FB Jr, Gosset F, Trinity RG, et al. Malignant interstitial cell testicular tumor. Cancer. 1973; 31: 120812. https://doi.org/10.1002/1097-0142(197305) $31: 5<12$ 08: : AID-CNCR2820310525>3.0.CO;2-6

[30] Rosai J. Ackerman's Surgical Pathology. Edinburgh, Mosby. 2004: 1436-7. 